\title{
Augmenting Ideological Machinery: Examining Pop Culture and its Influence on the Indian Youth Vote
}

\author{
Rwitoban Deb ${ }^{\mathrm{a}}$, Ishika Seal ${ }^{\mathrm{b}}$ \\ arwitoban.deb@gmail.com \\ a Policy and Communications Professional, Delhi, 110117, India \\ ${ }^{b}$ District Development Fellow, Government of Punjab, Sirhind City, 140407, India
}

\begin{abstract}
Once dismissed as a perfunctory relationship, in recent years the discourse on the relational understanding of popular culture and politics is one that has come into scrutiny, especially in the Indian political context. This paper seeks to investigate the deployment of the pervasiveness of consumerist pop-culture as an ideological state apparatus to influence popular perception in a world where the binaries of 'fact and fiction' lose meaning. Using the world politics and popular culture continuum framework to understand its scope and validity in the Indian context, this paper studies the inseparable relationship that politics and popular culture share in not just the physical, social and cultural space but also the digital one, by examining how Indian political parties have used popular culture as a site of propaganda or protest depending on their relationship with the sitting Government through the lens of the two biggest national parties in India, the Congress and the Bharatiya Janata Party (BJP). With the proliferation of social media and its increased relevance in elections, campaigning and the propagation of popular culture, this paper takes a caustic look at the young Indian voter tries to assess whether this calculated on-going campaign through influence of films, music, comics and art has been effective and contributed to mobilizing the youth voters who now constitute a key voter-base, with their increasing share in the Indian demography.
\end{abstract}

Keywords: Popular Culture, Politics, Youth

\section{Tracing theoretical Frameworks}

Challenging the notion that the study of International Relations entails the 'production of knowledge on interstate relations' (Wight 1960), a seismic shift was noticed in the study of International politics. With the binary of personal and political being broken down, scholars credited micro-political analysis crucial to understanding the impact of macro-political cultures of the everyday imagination. A shift of focus sought a keener eye for studying the individual as a site of politics; pop-culture with its palpable ubiquity then became a critical component of study. This micro political lens, further complicated the power structures of International Relations as it introduced new lenses of studying films, video games, music and in the current Indian context, even prime-time television news, bringing with it a wider spectrum of sources of power and information and hierarchies within the same, that can, and has been leveraged effectively by political parties in an attempt at influencing popular perceptions of reality.

In their pivotal work on Popular Culture World Politics, Davies, Grayson and Philpott (2009) argue that the relationship between popular culture and world politics should not be noted as one that converges at varying points instead, should be seen to occupy the same physical social and cultural space. It calls to question the traditional

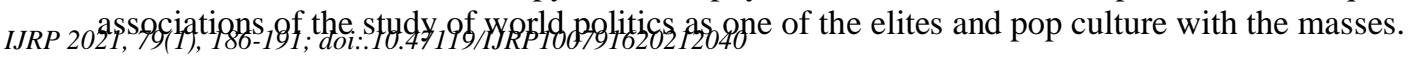


Popular culture, as a medium, does not prioritize a repository of facts, instead narratives hold the key. With blurring boundaries between the dichotomies of fact and fiction, compelling story-telling, backed with the support of the personality cult of mainstream actors, can weave a tapestry, creating a web of "synthetic experiences" that seeps into our perceived realities, reaffirming identities and hierarchies, aggrandizing joy or pathos as is convenient, sometimes even generating new ideas into public discourse. It is therefore inevitable that these impacts the decisions that are taken in the real world. ${ }^{1}$

Louis Althuser in his seminal work, 'Ideology and the Ideological state apparatus', carefully acknowledges popular culture as a vessel used by state structures to propagate their ideological beliefs. He posits that state structures ensure the reproduction of relations of power using the repressive state apparatus, and the ideological state apparatus. While repressive state structures use violence as means of suppression, ideological state apparatus seek to preserve power relations; some with a tacit tact, others with aggressive scrutiny.

"The political apparatus by subjecting individuals to the political State ideology, the 'indirect' (parliamentary) or 'direct' (plebiscitary or fascist) 'democratic' ideology. The communications apparatus by cramming every 'citizen' with daily doses of nationalism, chauvinism, liberalism, moralism, etc, by means of the press, the radio and television. The same goes for the cultural apparatus"2.

It is important to note that production and consumption of popular culture takes place in the industrial form, created and supplied in the market structure. A discursive negotiation between the audience and the producers create demand, in turn dictating supply. The modes of production and dissemination of popular culture and politics must also be examined in not just the physical, social and cultural space but also under the purview of the digital. Today, we live in the era of technology and social media. With the internet, we are constantly navigating the information overload. Applications like Facebook, WhatsApp, Instagram, and Share chat have taken over, digitizing the human experience. The 'world-politics and popular culture continuum' thus operates in one more domain, where popular culture is generated, consumed, and finds space to thrive. The algorithmic dictates, the culture of 'like-share and subscribe' and the creation of associations and echo chambers based on the same accompanied with the increased accessibility of information on the digital web, there is an increased popularization of popular culture. Political parties too have leveraged this space to collectivise, and organize themselves consolidating collective identities through online groups and communities, social categories of ingroup and out-group are replicated.

Contestations in the global flows of capital and culture pervades the domain of popular culture. Hierarchies manifest themselves in the form of Westernisation, Modernisation, Americanisation, Hybridization (Bhabha 1996), Homogenization, Cultural Imperialism (Tomlinson 1991) Sanskritization (Srinivas 2000) and Saffronisation among others. The Homogenisation of popular culture narratives are a reflection of the power structures of identities like race, caste, religion, gender among others. Industries like Bollywood and Hollywood, produce heavily consumed popular culture artefacts like films and music often categorizing identities and perpetuating stereotypes. It can be argued that these manifestations of asymmetry of power relations result in the dominance of majority, here too minorities are often coloured with the idea of 'other', for instance, the portrayal of India as the land of the snake charmers in Hollywood, Muslims as 'terrorists' and women as 'the second sex' are reinforced in our synthetic realities with this medium. Beyond the simplistic deployment of stereotypes, representations, narratives and intertextualities contribute to the creation of this cosmetic experience. However, it is important to note that the flow of popular culture is not unidirectional, and does not always follow the linear trajectory from the metropolis to the interiors. Instead, the flow of popular culture is multi-dimensional and has often nurtured cultures of protest and dissent. For instance, challenging the hegemony of the elite in the practice of classical music, the hip-hop revolution in its lyrical subversive verses took up the mantle of attacking the legacy of white supremacy, the deeply racial criminal justice system, and a clinical examination of life in the ghettos effectively leveraging popular culture as a means to accurately portray deliberately overlooked realities of inequality in the country that claims to be a front runner of equality and democracy.

Along with the politics of production, the politics of consumption too plays a key role in the understanding of popular culture. Actors, audiences, and institutions and their subjective realities and their position in the hierarchy become critical while breaking down the consumption of a given political artefact, producing a diverse reading for one object. For instance, it has also been interesting to note the contradictory positions often taken as the behest of political convenience when politicians on one hand resist the Homogenisation and Westernisation of popular culture with an aggressive agenda while at the same time preserving hierarchy through an emphasis on the propagation of 'sanskritized values', and the attribution of increased social, economic and legal capital to state structures that possess the ability to generate and heavily influence public opinion in their favour. Not just that, governments also retain the right to censor popular culture, and the right to punish purveyors of this crime. ${ }^{34}$

\subsection{Understanding the Indian Context}

Concretizing theory, this paper uses the framework of world politics and popular culture, to study and deploys it to the study what may be termed as the Indian politics and popular culture continuum. Using secondary 
research, it examines some key processes and events that have led to the popularization of politics in popular culture and their tangible manifestations in the voter choices, behaviours and motivations. Popular culture with its mass appeal and seamless relatability possesses the coveted power influencing and generating public discourse. This is effectively leveraged by political parties to preserve and perpetuate their authority and capital.

During election season especially, political parties on-board celebrity influencers to campaign for them. This allows them to utilize the cultural capital that has been acquired by pop cultural actors, and politically mobilize them for supporting their cause. Indian politics has also witnessed some key popular culture icons from the world of sport, films and television contest elections and more often than not emerge victorious owing to their mass appeal. Members of Parliament Smriti Irani, Hema Malini, Jaya Bachchan, Shatrughan Sinha, Gautam Gambhir can attribute their political success to the world of popular culture. While some icons take to the frontlines, others continue as allies.

As we trace the trajectory of the popular culture and world politics continuum in the Indian context, we have drawn out events that are symbolic of systemic and structural precedence of the relationship between the seemingly dissociated. This paper broadly examines this intersection of popular culture and electoral politics primarily by studying the extensive use of popular culture by BJP, India's ruling party at the Centre, through its impact on young voters, who are the primary consumers of popular culture.

\section{The marriage of popular culture and Indian politics}

Narendra Modi, India's Prime Minister since 2014, was seen discussing his choice of fashion sense and food in a candid interview ${ }^{5}$ with popular Indian actor Akshay Kumar leading up to the 2019 Lok Sabha polls. The carefree candour on display was a distant cry from Narendra Modi's antagonistic relationship with television interviews. While it polarised voters, who demanded far more accountability from a man of his stature ahead of elections, few could stop talking about it and channels televised the interview in tandem. The interview was on the lines of an episode from Ellen DeGeneres or James Corden's chat shows, which frequently feature world leaders like Barack Obama and Jacinda Ardern enjoying a hearty chat.

The 2019 interview was the crescendo to the concerted process that began in 2013 when BJP reworked their approach to pop culture to address their achilles heel, the youth voters. While Indian politics is mostly around caste and religious dynamics, 2014 saw the youth voters (18-25), between $22-25 \%$ of the total voters as calculated by Centre for the Study of Developing Societies, emerge as a vote bank. Along with the promise of more jobs, better economy, corruption-free India, BJP harnessed popular culture, undertaking a massive course correction from their earlier stand.

In the past, BJP stalwarts like L.K. Advani and Murli Manohar Joshi have consistently come across as confrontational and rarely somebody who the youth could relate to. Both were gradually phased out, as the two were not given any Cabinet positions in $2014^{6}$ and were not even offered tickets to contest the 2019 Lok Sabha elections. Atal Vihari Vajpayee was occasionally seen as a man beyond politics with his love for poetry, but few understood and harnessed the tools of pop culture as well as BJP under Narendra Modi.

BJP's campaigns since 2013 have been punctuated by memes, comics, catchy movie dialogues, and influencer onboarding. These contradictions and uneasy negotiations became apparent as BJP embraced what was always perceived as a liberal forte, while noted members of the party continued to decry it, on multiple occasions having said on record that these were an ill influence on Indian culture. Under the pretext of resisting the hierarchical flows of global culture, on several occasions BJP leaders made questionable remarks with deeply patriarchal undertones. However, these were heavily critiqued by members of the opposition and the citizenry as some perceived it as an obfuscation of our freedom of expression as guaranteed to us under Article 19 of the Indian Constitution. For instance, Babulal Gaur, former BJP Chief Minister of Madhya Pradesh, had said that the 'foreign culture' of women wearing jeans and T-shirts, and dancing with other men is not good for India ${ }^{7}$. Similarly, BJP Rajya Sabha MP Raghunandan Sharma claimed women shouldn't be allowed to use mobile phones or wear jeans ${ }^{8}$. Fast forward to 2019, BJP launched its campaign song ${ }^{9}$ titled My first vote to the one, one and only one who has got everything done, featuring young women and men, in colourful clothes which include jeans and shorts, flaunting tattoos, rapping and dancing to hip hop and Bharatnatyam dance steps.

\subsection{Films and perception building}

With a long-standing culture of glorification of actors, over the years this market-place of popular culture can be held liable for creating 'synthetic- experiences' that create, contradict, question and alter popular perceptions of reality. Bollywood's impact on Indians was something that Congress caught on very early on. Jawaharlal Nehru's vision of socialism found visual representation through films like Awaara $(1951)^{10}$ and Naya Daur $(1957)^{11}$ depicting the Indian social fabric while simultaneously surreptitiously disseminating the ideology of the state using popular culture as its means. Popular actor Manoj Kumar was advised by Nehru's successor, 
Lal Bahadur Shastri, to make a film advertising the popular slogan of "Jai Jawaan, Jai Kisaan", and Upkar (1967) was made. Congress also attempted to tap into the stardom enjoyed by the larger-than-life Bollywood actors. They fielded Amitabh Bachchan and Rajesh Khanna, arguably two of the biggest superstars of the latter half of the 20th century. While Amitabh Bachchan defeated Hemwati Nandan Bahuguna in Allahabad, Rajesh Khanna almost caused a major upset against BJP leader LK Advani in New Delhi in $1991^{12}$.

Not just to garner an increased vote share, but popular culture has also been used for strategic importance as political parties leverage it to sustain their seat of power. Erstwhile Congress Prime Minister Indira Gandhi had asked Doordarshan to screen the blockbuster of the 70s, Bobby, as a diversion tactic, redirecting public attention from a massive Janata Party rally and stop people from going to the rally that was convened against her, in the aftermath of the Emergency ${ }^{13}$.

It is critical to note that while on one hand, political parties have leveraged popular culture as a vessel for propaganda, it has also often emerged as a site of protest and dissent. For film-makers who choose to question majoritarian politics or the ruling party are often forced to bear the brunt of the repressive state structures. On several occasions political parties have demanded for bans to be imposed on movies which they believe do not concur with 'Indian values'. Movies like Deepa Mehta's Fire (1996) ${ }^{14}$ or Unfreedom $(2015)^{15}$ both tackling the nuances of same sex relationships were banned by the Censor-board, the former in a Congress led government, and the latter with BJP in the Centre. ${ }^{16}$

Much of BJP's politics has been built around its thrust on cultural nationalism. Keshav Baliram Baliram Hedgewar, founder of Rashtriya Swayamsevak Sangh, BJP's ideological forefather in RSS's mission statement had written, "the Hindu culture is the life-breath of Hindusthan. The Hindu culture is the life-breath of Hindusthan. It is therefore clear that if Hindusthan is to be protected, we should first nourish the Hindu culture."17

BJP's quest to preserve India's rich cultural heritage has often come at the cost of their leaders villainizing western culture, a blanket term often used to define various facets of pop culture such as films, TV shows, clothing, music originating from Western countries, as a direct attack on the Indian society and culture. RSS perceived western culture as an extension of colonialism and antithetical to their idea of Indian nationalism that built itself on pride and love for its rich legacy. "Hindutva" critics have noted the active propagation of this culture by government agents as antithetical to the secular principles that are embedded in our constitution.

Moreover, with the advent of global citizenship, this rarely struck a chord with the urban youth in India who had easy access to American sitcoms, British pop music and even South Korean films. This distanced the urban youth from BJP's politics, and found Congress as their preferred choice. In the three Lok Sabha elections preceding the 2014 elections, Congress' vote share remained consistent as they received 27\% (1999), 27\% (2004) and $28 \%$ (2009) percent of the youth votes while BJP's vote share was on a downward slope with $26 \%(1999)$, $23 \%$ (2004) and 20\% (2009) ${ }^{18}$. This necessitated an urgent introspection for BJP who had alienated youth voters, leading to a consistent decline in their vote share among the youth.

\subsection{A shift in strategy and perception}

This resulted in a marked shift in BJP's campaign strategies in the months leading up to the 2014 Lok Sabha elections. They overhauled their media and creative strategy, roping in advertising stalwart Piyush Pandey who is credited with the popular slogan 'Ab Ki Baar Modi Sarkar', lyricist Prasoon Joshi to write a party anthem, which was voiced by singer Sukhwinder Singh and turned into a music video ${ }^{19}$.

The 2014 assembly elections coincided with Indian Premier League, India's biggest sporting extravaganza, and India's very own 'ping pong diplomacy' was consumed by 462 million on television and another 300 million online in $2019^{20}$, majority of them youngsters. It was Piyush Pandey and animation expert Manish Sherawat, who made TV spots featuring Modi for broadcast during the matches. Peppered with satire, these 20-second long clips went viral among the youth, often at the expense of Congress, highlighting Narendra Modi's clean and vibrant image. ${ }^{21}$

From cricket to cinema, Narendra Modi was pictured in 3D glasses watching ${ }^{22}$ iconic Hollywood film Titanic $^{23}$ in Imax and making reference to popular Bollywood film Dhoom $3^{24}$ while mounting a political attack on his opposition Rahul Gandhi on Twitter ${ }^{25}$. The 2014 election campaign made BJP and Narendra Modi flashy, cool and most importantly, relatable to the young voters.

With holographic 3D technology, flash mobs, street art, street plays, stand-up comedy, it was less of a political campaign and more of a carnival. Narendra Modi even had his own comic series titled Bal Narendra with heroic tales of a young Modi. The highlight though was Chai Pe Charcha, which featured Narendra Modi sitting with common citizens and discussing issues in the country over a cup of tea. These informal sessions were then streamed live in a few thousand other locations across India.

"For the Rohini rally, we used radio, which we thought was the best way of reaching out to young people. For the March 26 Shastri Park rally, we put up 20 screens across the city. For the Rohini rally, we had put up about 100 LED screens all over the city," said Raj Shekhar Malviya, whose advertising agency was involved in the campaign, describing a mega rally in Delhi in the months leading up to the Lok Sabha elections ${ }^{26}$. In addition, 
BJP created youth-oriented commercials specifically for Channel (V), which primarily caters to a young audience. The message in one of the commercials was, "While we continuously update our status on Facebook, it is time to update the status of the country"27.

Social media was used unsparingly. Not only did messages get delivered through campaigns like "I Support Namo" on Facebook and Twitter but thousands of young volunteers were onboarded through these websites, many students, replicating the Aam Aadmi Party's success in Delhi Assembly elections in 2013. BJP had WhatsApp networks, ideology-based Orkut groups and Narendra Modi's YouTube channel ${ }^{28}$.

This was the first time where a political party had laid out an extensive plan to woo the youth voters and the youth responded. From 52\% and 54\% youth voter turnout in 2004 and 2009, there was a massive jump to 68\% in 2014 , even higher than the average overall polling percentage.

Of these young voters, $34 \%$ voted for BJP, an increase from $20 \%$ in 2009 and higher than its overall vote share of $31.1 \%$. Congress's vote share among the youth came down from $28 \%$ to $19 \%$, while for the Left parties, it decreased from $7 \%$ to $4 \%{ }^{29}$.

\subsection{Further mobilization post 2019}

Over the years, social media has become an active vehicle in the dissemination of popular culture. The number of active social media users in India at 330 million in 2019 and expected to reach 448 million by 2023, the BJP has successfully leveraged the twin forces of popular culture and social media to target the youth voter base. The Median age of the Indian population is 27.1 years. Millennials and Gen $\mathrm{Z}$ are the primary contributors for social media usage contributing over $80 \%$ of social media results. ${ }^{30}$ Needless to say, BJP's penetration into the youth has only further deepened post the 2014 election win. Not just Facebook, WhatsApp, Sharechat, the BJP along had a sizable footprint in Tik Tok too before it was banned in India. The marriage of social media algorithms that are designed to be addictive and feed us with information that keep us engaged and political parties that are looking to garner traction, community based social media echo chambers have been effectively leveraged to create the personality cult that Modi enjoys, the sentiment of awe and association penetrating even in areas where parties did not have an on-ground presence.

Narendra Modi holds meetings with the A-Listers of Bollywood, posts selfies with them which go viral within seconds ${ }^{31}$ and gives television interviews speaking about the less serious aspects of life. Movies like Vicky Kaushal starrer Uri: The Surgical Strike ${ }^{32}$ which brings to life the attack on militant camps across the LOC by the Indian army, while many of Akshay Kumar's films have a Modi Government scheme as a central motif, helping in narrative building and evoking a strong sense of nationalistic pride. Narendra Modi even had his own biopic released during the 2019 Lok Sabha elections. All of this resulted in a resounding victory and an even bigger mandate for Narendra Modi and the BJP in 2019 with $41 \%$ of the youth between the age bracket of 18-22 and $40 \%$ of those between 23-27 voting for BJP33.

\section{Conclusion}

A study of the varying aspects of 'Indian politics and popular culture continuum' highlights how the sociopolitical economy of the production and consumption of popular culture plays an instrumental role in the creation and alterations of identities and discourses. The several intertextualities in understanding of popular culture force us to look at how subjective social positions give way to a plurality of narratives, with the same film, video game or art evoking different sentimentalities and therefore creating a multiplicity of synthetic experiences and imaginations that translate into real world choices. The pervasiveness of pop-culture in the everyday reality is thus apparent. Over the years, political parties have leveraged popular culture not just as a vessel for propaganda but as a strategic site of narrative building, direct engagement and effective election campaigning. With the increased role of social media in elections and as a medium for propagation of pop-culture; this study highlights the increasing importance of the digital space, especially with regard to the youth who make up the majority of social media users, emerging as a critical voter-base.

While a singular linear causal link cannot be drawn between the role of popular culture in BJP's mobilisation of youth votes in 2014 and 2019, BJP's thrust on using pop culture elements as part of their electoral campaigning does coincide with a sharp increase in youth votes for the party. Another indicator to measure its impact on BJP's youth outreach is that their vote share grew more among the urban youth compared to their rural counterparts, with the tools to consume pop culture still more accessible in cities and towns. There were other factors which resulted in BJP's decisive mandate among youngsters which include anti-incumbency, a weak opposition, promise of jobs and better economy but it was the extensive and efficient use of popular culture tools and references which played a pivotal role in ensuring the message reached its intended audience. 


\section{References}

1. "So, How Does Popular Culture Relate To World Politics?". E-International Relations, 2015, https://www.e-ir.info/2015/04/29/so-howdoes-popular-culture-relate-to-world-politics/. Accessed 31 Aug 2020.

2. Csun.Edu, 2020, http://www.csun.edu/ snk1966/Lous\%20Althusser\%20Ideology\%20and\%20Ideological\%20State\%20Apparatuses.pdf. Accessed 30 Aug 2020.

3. Banerjee, Ayush. "How 'Pop-Culture' Influences 21St Century International Politics - International Association For Political Science Students". Iapss.Org, 2020, https://www.iapss.org/2018/06/08/how-pop-culture-influences-21st-century-international-politics/. Accessed 31 Aug 2020.

4. Bleiker, Roland \& Duncombe, Constance. (2015). Popular Culture and Political Identity. e-International Relations, special issue edited by Federica Caso and Caitlin Hamilton.

5. 2020, https://www.youtube.com/watch?v=rPIT6-PL050. Accessed 31 Aug 2020.

6. AURORA, BHAVNA. "With No Post, L K Advani And Murli Manohar Joshi Appear To Have Made Peace With Their Fate". The Economic Times, 2014, https://economictimes.indiatimes.com/news/politics-and-nation/with-no-post-1-k-advani-and-murli-manohar-joshiappear-to-have-made-peace-with-their-fate/articleshow/35624585.cms.

7. PTI. "Foreign Culture Allows Women To Wear Jeans And Drink. It's Good For Them But Not Us, Says MP BJP Leader". India Today, 2013, https://www.indiatoday.in/india/north/story/mp-bjp-leader-babulal-gaur-western-culture-indian-women-151579-2013-01-14.

8. News, India. "No Cellphones For Unmarried Girls, No Jeans For Women: BJP MP | India News - Times Of India". The Times Of India, 2013 ,

MP/articleshow/20529791.cms.

9. 2019, https://www.youtube.com/watch?v=313nuAAdXcc. Accessed 31 Aug 2020.

10. "Awaara (1951) - Imdb". Imdb, 2020, https://www.imdb.com/title/tt0043306/.

11. "Naya Daur (1957) - Imdb". Imdb, 2020, https://www.imdb.com/title/tt0050758/.

12. "Soft Power For Hard Messaging". Dailyo.In, 2019, https://www.dailyo.in/arts/bollywood-for-politics-narendra-modi-shahrukh-khanaamir-khan-ektaa-kapoor-indira-gandhi-manoj-kumar-upkar-bobby/story/1/32123.html.

13. "When Bobby Could Not Stop People From Attending A United Opposition Rally During Emergency: Jaitley". India Today, 2018, https://www.indiatoday.in/india/story/when-bobby-could-not-stop-people-from-attending-a-united-opposition-rally-during-emergencyjaitley-1270090-2018-06-26.

14. "Fire (1996) - Imdb". Imdb, 2020, https://www.imdb.com/title/tt0116308/. Accessed 31 Aug 2020.

15. "Unfreedom (2014) - Imdb". Imdb, 2020, https://www.imdb.com/title/tt2049630/. Accessed 31 Aug 2020.

16. Arora, Gaurav. "15 Indian Movies That Got Banned By The Censor Board". Scoopwhoop.Com, 2015, https://www.scoopwhoop.com/entertainment/banned-hoon-main/. Accessed 31 Aug 2020.

17. "Vision And Mission". Rss.Org, https://www.rss.org/Encyc/2012/10/22/rss-vision-and-mission.html.

18. The Youth Vote Made A Massive Difference For The BJP. Research Journal Social Sciences, 2014, https://www.lokniti.org/media/upload_files/PU-\%20The-Youth-Vote.pdf. 10Accessed 31 Aug 2020.

19. Dasgupta, Pritha. "From Narendra Modi To Brand Modi: Meet The Team Behind BJP's Unprecedented Poll Campaign". The Economic Times, 2014, https://economictimes.indiatimes.com/news/politics-and-nation/from-narendra-modi-to-brand-modi-meet-the-team-behindbjps-unprecedented-poll-campaign/articleshow/34452319.cms?from=mdr.

20. Laghate, Gaurav. "IPL Viewership: IPL 2019 Breaks Viewership Records". The Economic Times, 2020, https://economictimes.indiatimes.com/news/sports/ipl-2019-breaks-viewership-records/articleshow/69483861.cms?from=mdr.

21. NP, Ullekh, and Ullekh NP. "Abki Baar Modi Sarkar: Whose Line Was It Anyway?". Scroll.In, 2020, https://scroll.in/article/721624/abkibaar-modi-sarkar-whose-line-was-it-anyway.

22. "Which Movie Did Narendra Modi Watch In A Cinema On Monday?". NDTV.Com, 2013, https://www.ndtv.com/india-news/whichmovie-did-narendra-modi-watch-in-a-cinema-on-monday-515883.

23. "Titanic (1997) - Imdb". Imdb, 2020, https://www.imdb.com/title/tt0120338/.

24. "Dhoom 3 (2013) - Imdb". Imdb, 2020, https://www.imdb.com/title/tt1833673/?ref_=fn_al_tt_1.

25. "Twitter". Twitter.Com, 2020, https://twitter.com/narendramodi/status/454928560470257664?lang=en. Accessed 31 Aug 2020.

26. "Rallies Reloaded: Redefining Poll Meetings, The BJP Way". Hindustan Times, 2020, https://www.hindustantimes.com/india/ralliesreloaded-redefining-poll-meetings-the-bjp-way/story-6kDpLZj4HuTzZ2TM5CDQJJ.html.

27. Dasgupta, Pritha. "From Narendra Modi To Brand Modi: Meet The Team Behind BJP's Unprecedented Poll Campaign". The Economic Times, 2014, https://economictimes.indiatimes.com/news/politics-and-nation/from-narendra-modi-to-brand-modi-meet-the-team-behindbjps-unprecedented-poll-campaign/articleshow/34452319.cms?from=mdr.

28. "How BJP's Online Campaign Proved Vital For Success - Business Today". Web.Archive.Org, 2014, https://web.archive.org/web/20140522044909/http://businesstoday.intoday.in/story/bjp-online-campaign-aam-aadmi-party/1/206389.html.

29. The Youth Vote Made A Massive Difference For The BJP. Research Journal Social Sciences, 2014, https://www.lokniti.org/media/upload_files/PU-\%20The-Youth-Vote.pdf. Accessed 31 Aug 2020.

30. "Digital Trends 2019 \& Social Media Landscape In India". Sannam S4, 2020, https://sannams4.com/digital-and-social-media-landscapein-india/\#: :text=Median\%20age\%20of\%20India\%20is,from\%20those\%20aged\%2035\%2D44. Accessed 31 Aug 2020.

31. https://www.huffingtonpost.in/entry/narendra-modi-ranveer-singh-bollywood-bjp-selfie-ranbir-kapoor-alia-bhatt-vickykaushal_in_5cd0211de4b0548b735d1615

32. "Uri: The Surgical Strike (2019) - Imdb". Imdb, 2020, https://www.imdb.com/title/tt8291224/.

33. "Post-Poll Survey: BJP, The Most Preferred Party Of Young India". The Hindu, 2020, https://www.thehindu.com/elections/lok-sabha2019/the-most-preferred-party-of-young-india/article27277454.ece. 